\title{
Kantian Cosmopolitan Ideal in Disciplining the World Literature: Cosmopolitanism in Hong Kong Poetry in the Early 1990s
}

\author{
James AU Kin-pong \\ University of Tokyo, Tokyo, Japan
}

\begin{abstract}
This article looks at how cosmopolitanism - the notion of universality within a diversity of multi-cultures - has been shaping the discipline of world literature. The article encompasses chiefly three parts. The first part offers an overview of the debates on the discipline widely discussed by literary scholars such as Franco Moretti, David Damrosch and Emily Apter. I take issue with the harmonic co-existence of both local and global elements-and what I define as "glocality"-in literatures to exhibit the inevitable trend of the trans-cultural, supranational and cross-historical interactions among multiple centres and/or various cities especially in the twenty-first century. I thereby argue in the second part using Leung Ping Kwan (1949-2013)'s "Images of Hong Kong" (1992) and Louise Ho's two poetry pieces written in 1994 to prove how Kantian Cosmopolitan elements have deeply embedded in the poem written in a city where the West frequently interacts with the East. I conclude by stepping in further to argue that only through tolerating and mediating between the region and the globe can world literature as a discipline find its way out without fear for marginalising any of the literary pieces.
\end{abstract}

Keywords: cosmopolitanism, universality, Immanuel Kant, world literature, Hong Kong

\section{Introduction}

Two decades have passed even since the transfer of sovereignty over Hong Kong from the United Kingdom to The People's Republic of China. While ethnitically speaking, Hongkongese are of Chinese origin, some of them differ themselves from mainland Chinese, as the city was colonized and the citizens obviously have a different style of education from their northern brother. The rise of nativism - a form of ethnocentrism in which Hongkongese regards holding a British citizenship more superior to a Chinese one - is getting stronger after a series of controversies, including the government's alleged implementation of national education and the failure to pass the universal suffrage in which Hong Kong people enjoy the right of one-man-one-vote system. More fear Hong Kong may eventually become one of the ordinary Chinese cities, and lose its uniqueness forever. Under these circumstances, how can Hong Kong people retain the uniqueness of the city? While interaction between Hong Kong and other Chinese cities is inevitably becoming more

James AU Kin-pong, research postgraduate at University of Tokyo. His research interests include Asian literatures, historical novels, philosophical representation in literary texts and comparative literature. He earned his degrees from Chinese University of Hong Kong, Hong Kong Baptist University and School of Oriental and African Studies, University of London. A number of his poems and translations have been published in various magazines and journals. His recent published article is "Nihilism and Crisis: A Comparative Study of Yu Da-fu's Sinking and Akutagawa Ryūnosuke's Rashōmon." (Japan Studies Review (2016), Volume $\mathrm{XX}, 29-52)$. 
rigorous, how can we strike a balance between resepecting the culture of others and keeping our own selves? To answer these questions, I would like to look at the idea of cosmopolitanism, and how local writers in the early 1990s responded to the changing political landscape of Hong Kong, which may help us escape from the present political and social cul-de-sac.

\section{The Fulfilling Prophesy of Kantian Cosmopolitanism Model}

"I am not an Athenian or a Greek," the famous philosopher Socrates once remarked, "I am a citizen of the world." Astonishing as it is when we consider the sage was like forecasting what might have happened few thousand years later, the world, from the early nineteenth century till the twentieth-first century, has gone more cosmopolitan by which I mean we sense that we are residing in the same world which underscores both universal humanity and morality, and is projected to go more cosmopolitan. Following the old sage's thoughts, Immanuel Kant (1724-1804) proposed a more comprehensive model on a world as universality in his essay "Perpetual Peace" (1795) where he extrapolates how the state should be more accommodating to foreign ones while maintaining a certain degree of autonomy as he asseverates that "No state shall forcibly interfere in the constitution or government of another state" (Kant, 1970, p. 96). Viewed as an introduction to his later suggestion to establish world peace by granting privilege of foreigners to freely interact with the locals (Kant, 1970, p. 106), Kant defended in every aspect the cosmopolitan values. From the title as it suggests, the German philosopher might be responding to the political instability - his fear of division of Poland, as scholar Bachmann analysed (Lutz-Bachmann, 1997). Though his essay was a result of pure political motivation, it is nonetheless highly relevant to the issue the discipline of world literature is facing-more massive in amount and more fluid thanks to more frequent world trades and more affordable flights expenses which make long-distant travel from one continent to another more possible than ever before.

Then the problem with which we are confronting is how we can handle, or by which criteria we should obey to select a piece of literary work in this cosmopolitan world given that we are flooded with "superabundance of materials" (Auerbach, 1952, p. 8) and plagued with the unattainability of the "total sum of all national literatures" (Guillén, 1993, p. 38). Kant indeed has provided us with a clue in the issue, i.e. to embrace our own nature as he reiterates several times. Nature, from Kantian perspective, involves both analytical and synthetic knowledge. Specifically speaking, in Yeats's use of rose metaphors in his poetry, he was definitely affected by his own visual or sensational perception (synthetic knowledge) and his first instinct of association with his feelings (analytical knowledge). Because of the twin modes of knowledge, cosmopolitanism has thereby avoided having created a monotonous world and instead it has enabled the globe to accommodate various forms of cultures all of which sum up to form a harmony. In other words, a world literary piece should embrace and contain both global and local values that create uniqueness within the entity. Shakespeare would not have been widely read, circulated and analysed if his plays had not been set in various places such as Venice and Denmark while he himself began the precedence of a unique rhythm and meter throughout most of his masterpieces. What Damrosch expounded upon his idea of circulation is thus, from my perspective, a priori result from the co-existence of the culturally universal and specific- "glocal" elements without which a literary piece can hardly gain popularity and fascinate global citizens. A central point of focus of this essay will then explore how Hong Kong impinged by its geographical location and historical factors, is 
exceptionally gifted to conceive the cosmopolitan literary works.

\section{One of the Multiple Centres as a Propeller of World Literature—Hong Kong}

Three years ago (2014), led by David Damrosch, the Institute for World Literature, which I attended in the former British colony Hong Kong, was successfully held and on a rough estimate, more than one hundred and fifty scholars have been convoked to discuss methodologies and teaching syllabi of the discipline. From the cities Damrosch's team carefully selected from 2011 to 2015 and ranging from Peking, Istanbul, Cambridge, Hong Kong and to Lisbon, we can conjecture his intention to speed up the circulation process and to foster better understanding of the world's literary canon and to dig out, in his three tier canonical system, the valuable regional "shadow canonical works"- "works written by "minor' writers who fad increasingly into the background of scholarly knowledge" (Damrosch, 2003, p. 45). Now here come few questions: Why is Hong Kong perceived as a hub of literary interaction? Under the assumption I made earlier that a work must be glocal, how does the city's literature uphold Kantian cosmopolitan principle exhibiting its uniqueness and harmony concurrently? How do the cosmopolitan values bring about new possibilities of literary aesthetics?

Needless to say, the city's culture encompasses both elements of the East and the West because of its colonial history traced back to 1842. Although Said blamed colonialism as a cause of supressing the voices of the marginalized because of politics and power at their full play, I would argue the process nonetheless gave rise to more diverse form and style of literary arts, or to be more specific the amalgamation of both Chinese and Western ideas. Hooper smartly observed Hongkongers' use of code-mixing, the melange of English and Chinese phrases in the colloquial languages (Hooper, 2003, pp. 25-26). Because of the unique linguistic hybridity, local literary writers always portrayed hospitality to people from around the globe. For instance, in the local born writer Louise Ho's short poem "Home to Hong Kong" (1994) written in English, she expressed the cosmopolitan nature of the city where people irrespective of their origin can feel like they are at home:

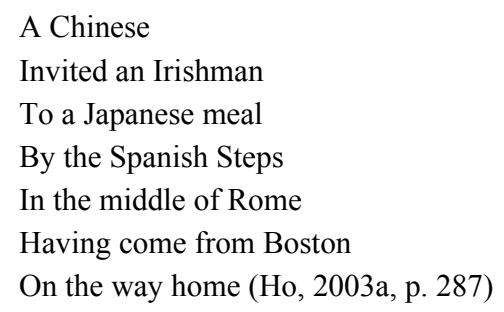

The poem exhibits the enormity of the world outlook the poet possesses, as it, except in the last line, mentions a different place. The persona here resembles someone going around the world and returns home at last. While the vivid images of metropolitan where friends with various races met each other, the poem also exudes the sense of belonging to her own home. Just as Kerr concluded, the beauty of this piece does not lie in the linguistic originality, nor is it stylistically appealing (Kerr, 2010, p. 77). Nevertheless, he gets the gist of Ho's writing: she is to tell us a story about a "Chinese cosmopolitanism" (Kerr, 2010, p. 77) through the persona's "sociable globetrotting" (p. 80), and in addition, it forms a euphony from the signification of the "melting pot", the phrase of which local media, merchants and citizens adopt to position the city as a site of fusion between Chinese and western cultures. Such a liberal thought of integration is not only corroborated by the context of the poetry, but also by her writing in English and linguistic description. In the poem 
"Well-spoken Cantonese" written by the same author in the same year, it was as if she was introducing native culture to western readers and extolled the beauty of her mother tongue:

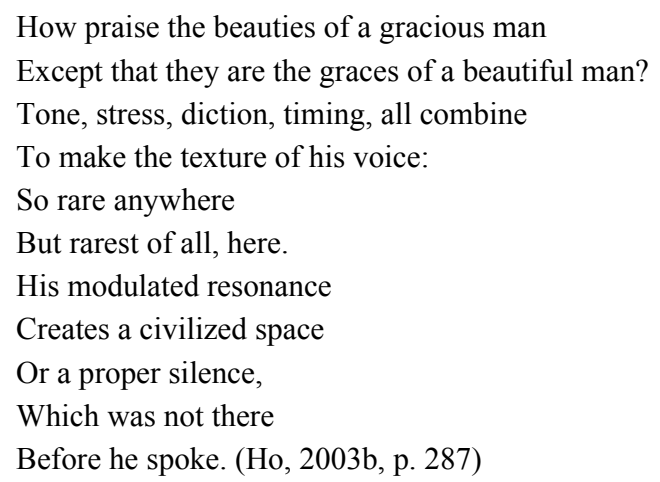

We can see, in many aspects that Ho underscored the uniqueness of one of the Chinese macro languages. More interesting in particular is her use of English to portray the Cantonese community in the poetry, signalling the dynamics of Hongkongers - on one hand they are eloquent in the world's most used language, on the other hand they "modulate" (see Line 7) themselves into their own lingua franca to merge to another social group. Now a question is raised here: Given Ho's position as a native Cantonese speaker, why did she select English as her tool for self-expression? I refuse using Gramsci's master-slave relation to answer the question since people of Hong Kong have been granted freedom to employ the twin languages, and the British colonial government had granted equal importance on both types of discourses. Nor am I satisfied with Spivakian theory in viewing English as the only tool to permit the marginalized to have a voice to speak for them, and in contrast, they are more privileged as the city serves more like a bridge between China and the west. Kerr also defied the existence of postcolonial scenarios in Hong Kong (Kerr, 2010, p. 83), since Hong Kong literati are merely conscious about the unshakable influence of English as a world language, or in other words, they are sufficiently aware of creating "world literary space" (Casanova, 2005, p. 72), by which Casanova suggests literature and the world being neither mutually exclusive to each other, nor is the former a bare subset of the latter. Though Damrosch interpreted Casanova's view as more like a global phenoitmenon, I take a step further in asseverating that the intention of such a linguistic choice is rather the writers' consensus of universal human nature, as Kant proposed. By "a civilized space" (see Line 8) Ho pointed to the mediation between the local and the global to emphasize the importance of "resonance" or in Kantian term, peace. In this respect, Kerr is right to point out the writer's endeavour of collaboration between "the medium of written English and the subject of Cantonese speech" (Kerr, 2010, p. 87), that is, Hong Kong writers possess the forethought and foresight of a universally applicable practical reason - the presupposition of global intuition and experience despite, while crossing from one culture into another, some differences in particularities, which is the diverse intonation, use of various vocabularies, and other linguistic uniqueness of Cantonese mentioned in the poem (see Line 3).

\section{The Adjustment of the Shot for Mediation}

Kantian cosmopolitan features are not simply reflected in the language and style, but also in the images described by the poet. In Leung Ping-kwan's "Images of Hong Kong” originally written in Chinese and later 
translated collaboratively with Gordon T. Osing, the local born poet presented to us a various perspectives to view the modern city:

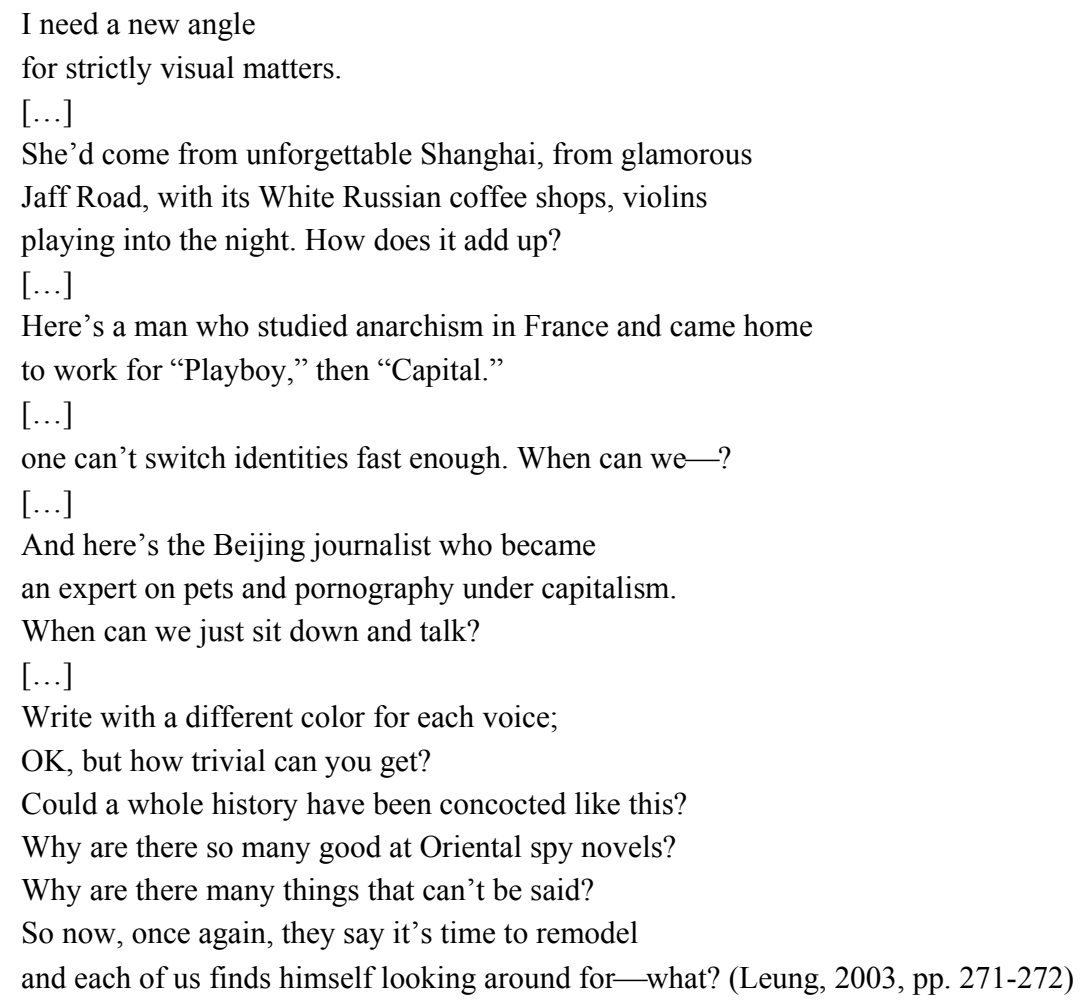

The persona in the poem, from the outset, is generally perceived as a cameraman looking for a "new angle" (see Line 1) to (re)capture every corner of the city from a fresher angle, but the essence in these two lines is to arouse readers' consciousness about rapid changing surroundings by showing in subsequent lines various image fragments. Chinese scholar Rey Chow attempted to analyse, from both Freudian and feminist perspectives, Leung's poetry in which they depicted the loss of a Hong Kong identity with his motherland as a result of British colonialism (Chow, 1998, pp. 171-175) and lamented for the fading of past culture under the inevitable influence of capitalism and consumerism (p. 170). However, instead of bemoaning pessimistically what people lost, Leung asked his readers to be more reflective on our transforming temporal space. He was fully aware when he wrote this poetry five years before Hong Kong's return of sovereignty to China that changes in the city geographical and political landscapes naturally lead to a new negotiation method and a re-positioning of Honkonger's changing identities.

The constant mediation between space of unity and particularities is more salient from the characters of a Shanghainese woman, an anarchist scholar and a Beijing journalist. Their ethnic background, their travel and their occupation speak cacophonous voices with one another. For instance, anarchism and capitalism are almost two opposites of one another since the former is a belief that champions no government and authority while the latter advocates a market-driven society and the existence of government. In "Images of Hong Kong", nonetheless, the persona was described as having studied "anarchism in France" (see Line 6) and returned home to work at a famous adult magazine "Playboy" (see Line 7), which witnessed great success in the 
capitalist American society in the 1950s. The scent of capitalism becomes more pungent when he was later said to work at "Capital" (see Line 7), a magazine aiming at readership of management group or chief executive, all of which are products of capitalist society. The bricolage of the scenario, however, implicitly reflects the high adaptability on which the poet as a citizen also prides. Anarchism also has strong affinity with communist China since the idea served as a catalyser to trigger the Russian Revolution in the late 1910s and later the rise of Chinese communism (Ward, 2004, pp. 19-20). Similarly from the example of the "Beijing journalist" (see Line 9), we can see how a person had to develop strong adjustability to change his stance readily between right wing and left wing. Following this logic, we shall be convinced that Leung narrated the seemingly incompatibles - Western capitalism and Chinese communism — existed side-by-side in the city. But crowned as a cosmopolitan city, Hong Kong people have to be as flexible as water to "switch identities" (see Line 8) even though they "can't" (see Line 8). It is thus this people's consciousness of China-West difference that mandated them to constantly change their angle of actions and behaviour in order to abide by their own unique situation. Such conformity thereby synchronizes Kantian's universalism the criterion of which ultimately results in peace across the world (Scruton, 2001, pp. 114-115), as also suggested by Scruton.

The five consecutive questions in the last few lines of Leung's poems undoubtedly urged local readers to reflect on the city's possible future path. Hong Kong is, as mentioned earlier a "melting pot", where people with "different colors" (see Line 12) cohabit in the same city but the sundry races likewise proves to be problematic as they are roughly categorized by a large umbrella term "Hongkonger" in lieu of "trivial[ly]" (see Line 13) dividing them into groups like Pakistan-hongkongese and Indian-hongkongese. Leung's second interrogation, nevertheless, begged people to think about the particularities other than blindly consenting to other cultures. How the history can be constructed appropriately thus relies upon self-awakening of the locals to rethink about the idea of cosmopolitanism— town people are all good negotiators, thus they absorbed ideas from China and the West and wrote good "Oriental spy novels" (see Line 14) but they sacrificed concurrently their thoughts, forgot to appreciate cultures (I use plural here because it is the multi-ethnicity, and it is the multi-cultural elements that constitute the city as a whole) of their own and cease to talk about it. Leung here offered a prime opportunity for everyone to, like Kant's suggestions, give finer category and to reset the meter that can optimize the situation - an ideal in which the globe and the local are equally represented in the city, including its literature.

\section{Cosmopolitanism as a Means to Going Global}

Though outlined concretely by Kant more than two centuries ago, the idea of cosmopolitan cities is gaining ground nowadays, and because of recurrent interaction among people across the globe, it is inevitable for the interweaving of European, African, Asian or other elements embedded in the literary works, which I have spent almost two whole sections substantiating. Damrosch has foreseen this phenomenon, but he made too great a stride in sparking the debate of circulation prior to clarifying the formation of those "best-read works" (Damrosch, 2003, p. 5). The instances of the above poetry I cited were thus aimed at demystifying the unsolved issue through linguistic, stylistic and contextual analyses, which I deemed more comprehensive than one might have originally expected. Apter once raised her concern about the high demand of linguistic competence of a scholar when engaging himself/herself with cosmopolitanism or word literary studies and suggested a serious 
address to translation as a means to shaping the discipline of what she coined "new comparative literature" (Apter, 2003, pp. 54-77). However, her proposal of focussing on postcolonial monolingual studies severed the thread of any city's literature with other cultures. Likewise, referring back to the example of Hong Kong, putting all spotlights on anglophone writing is apparently not enough given the "trilingual and bi-literate" education policy emphasized by the government. Thus, the task of a world literature scholar will be then to possess as many multilingual skills as possible even though ultimately a universal language is required to spread the message across the world. Some, like Moretti, might view this Kantian universalism as "one and unequal" (Moretti, 2000, p. 56) but his assertion was hypothetical that English is forever dominant, or that European/American culture will be eternally prevailing. His claim was, I think, constrained in a stable, stagnant temporal entity. True as it is to say that English nowadays is the world's most-used language, who can dare say that the situation will remain the same in the future? While I appreciate his metaphor of "literary interference" (Moretti, 2000, p. 56), it is not as what he says an extremely skewed asymmetry. Instead, each point of interference resembles a particular time at which the two or more literary elements either sum up to form a greater work, or they temporarily cancel out each other, but are incubated for the birth of another great canon.

Let me make three points here. First, constant cultural interaction means our conception and experience of cultures keeps transforming synchronously. Therefore, we are in face of continual negotiation. Yet it is through negotiation that we always discover new meaning and metaphors, and this new discovery allows us to taste the uniqueness of cosmopolitan literature. Readers very often find a series of familiar images unfamiliar when strung together, as Louise Ho and Leung Ping-kwan have already showed us. Second, negotiation is never a unilateral negotiation but a multilateral one. Andrew Parkins, for instance, an England born writer, had lived in Hong Kong for several years and was once a chair of English at the Chinese University of Hong Kong (XU \& Ingham, 2003, p. 279). He had written a number of poems about Hong Kong based upon the experiences of his stay. The word limit here has forbidden me to delve deeply into his works, though. His poetry, say "Hong Kong Tanka" (p. 311) is absolutely different from his contemporary British peers in terms of forms and styles, and his Parisian-flavoured poems at present give readers another sensation. Therefore, stubborn writers who solely exercise their subjectivity without a certain degree of elasticity results in defected aesthetics because they seldom learn to empathize, leading to a narrow group of readers. Cosmopolitan writers, on the other hand, grow more accustomed to both universal experience and their first instincts, thus able to appeal to readers worldwide. Third, I would like to refute those who unequivocally view colonialism as a necessary condition for cosmopolitanism. Hong Kong surly was colonialized and thus historically and geographically formed a bridge of interaction between China and the West, yet many other cosmopolitan cities such as London, Paris and Tokyo do not bear the colonial burden but have still given rise to many good-reads as well. Thus, cosmopolitanism should not be limited by its place of origin, but be perceived as an attempt to oscillate incessantly between region and the globe, and to eventually win global attention.

\section{Conclusion}

I think I have made a point in this article: Colonialism should not always be perceived negatively, but people whose nations were colonized can now benefit from knowing both local and global culture, and the amalgamation of various cultures gives rise to a new, unique culture. If Ezra Pound had not misunderstood 
Chinese and mistranslated the classical Chinese poetry into English, the creative imagism would not have appeared in the early 20th century. Therefore, I believe creativity always rises from the melting of various cultures. But while remaining open-minded to foreign cultures, Hong Kong writers should also strive hard to protect their own one to prevent it from being assimilated, and to defend the city before it turns to be monolingual and monocultural.

\section{References}

Apter, E. (2003). Global translation: The "Invention" of comparative literature, Istanbul, 1933. Translation/Transnation: Translation zone: A new comparative literature. New Jersey: Princeton University Press.

Auerbach, E. (1952). Philology and weltliterature. (Maire and E. Said, Trans.). The Centennial Review 13, 1 (Winter 1969), 1-17. Casanova, P. (2005). Literature as a world. New Left Review 31, (Jan-Feb), 71-90.

Chow, R. (1998). Things, common/places, passages of the Port City: On Hong Kong and Hong Kong author Leung Ping-kwan. Ethics after idealism: Theory-Culture-Ethnicity-Reading. Bloomington : Indiana University Press.

Damrosch, D. (2003). Introduction: Goethe coins a phrase. What is world literature? Princeton: Princeton UP.

Damrosch, D. (2006). World literature in a postcanonical, hypercanonical age. In H. Saussy (Ed.), Comparative literature in an age of globalization. Baltimore: The Johns Hopkins University Press.

Damrosch, D. (2009). Frames for world literature. Grenzen der literature. Winko, Simone et al., (Eds.). Berlin and New York: Walter de Gruyter.

Guillén, C. (1993). The challenge of comparative literature. (Franzen \& Cola, Trans.). Cambridge, Massachusetts, and London: Harvard University Press.

Harvard. (2015). The institute of world literature. Retrieved from http://iwl.fas.harvard.edu (Web. 17th April 2015).

Ho, L. (2003a). Home to Hong Kong. City voices: Hong Kong writing in English 1945 to the present. X. XU and M. Ingham, (Eds.). Hong Kong, Hong Kong University Press.

Ho, L. (2003b). Well-spoken Cantonese. City voices: Hong Kong writing in English 1945 to the present. X. XU and M. Ingham, (Eds.). Hong Kong, Hong Kong University Press.

Hooper, B. (2003). Voices in the heart: Postcolonialism and identity in Hong Kong literature. Frankfurt am Main: Peter Lain.

Jameson, F. (1986). Third-World literature in the era of multinational capitalism. Social Text, 15(Autumn 1986), 65-88.

Kant, I. (1970). Kant: Political writings. (H. B. Nisbet, Trans.). Cambridge: Cambridge University Press.

Kerr, D. (2010). Louise Ho and the Local Turn: The place of English poetry in Hong Kong. Hong Kong culture: Word and Image. L. Kam, (Ed.). Hong Kong: Hong Kong University Press.

Leung, P-K. (2012). City at the end of time: Poems by Leung Ping-kwan. E. M. K. Cheung, (Ed.). (G. T. Osing \& P-K. Leung, Trans.). Hong Kong: Hong Kong University Press.

Lutz-Bachmann, M. (1997). Kant's idea of peace and the philosophical conception of world republic. Perpetual peace: Kant's cosmopolitan ideal. J. Bohman and M. Lutz-Bachmann, (Eds.). New Baskerville: MIT Press.

Moretti, F. (2000). Conjectures on world literature. New Left Review 1, Jan Feb 2000, 54-68.

Scruton, R. (2001). Kant: A very short introduction. Oxford: Oxford University Press.

Spivak, G. C. (2003). Crossing borders. Death of a discipline. New York: Columbia University Press.

Ward, C. (2004). Anarchism: A very short introduction. Oxford: Oxford University Press.

Wellek, R. (1959).The crisis of comparative literature. The princeton sourcebook in comparative literature. D. Damrosch, M. Natalie, and M. Buthelezi, (Eds.). Oxford: Princeton University Press.

XU, X., \& Ingham, M., (Eds.). (2003). City voices: Hong Kong writing in English 1945 to the present. Hong Kong: Hong Kong University Press. 